\title{
Towarzystwo im. Michała Kaczkowskiego
}

\author{
o. ihumen Sergiusz (Matwiejczuk) \\ Męski Klasztor Zwiastowania NMP w Supraślu \\ bogdan_mat@poczta.onet.pl
}

o. ihumen Sergiusz (Matwiejczuk), The Michal Kachkovsky Society, Elpis, 19 2017: 207-210.

\begin{abstract}
The main aspect of this article is to study cultural-educational institution's activities the Michal Kachkovsky Society and reading rooms of his name on Lemkivshchyna. The society was founded in the second part of the XIXth century. The main purpose of this institution was cultural and educational activity among the Lemko people. The most part of the Kachkovsky reading rooms was established in Gorlice County and Orthodox priests took also part in their activity. This article also concerns Michal Kachkovsky itself and his educational activity.

Streszczenie: Głównym zagadnieniem niniejszej pracy jest badanie działalności organizacji społeczno-oświatowej Towarzystwa imienia Michała Kaczkowskiego oraz czytelni jego imienia na Łemkowszczyźnie. Towarzystwo zostało założone w drugiej połowie XIX wieku. Głównym celem organizacji była działalność społeczno-oświatowa wśród Łemków. Najwięcej czytelni im. Kaczkowskiego powstało w powiecie gorlickim, a prawosławne duchowieństwo uczestniczyło w ich działalności. Niniejszy artykuł dotyczy również osoby samego Michała Kaczkowskiego i jego działalności oświatowej.
\end{abstract}

Key word: Michal Kachkovsky, The Michal Kachkovsky Society, the Lemko people, reading rooms

Slowa kluczowe: Michał Kaczkowski, Towarzystwo im. Michała Kaczkowskiego, Łemkowie, czytelnie

Michał Kaczkowski urodził się 29 lipca 1802 r. we wsi Dębino w powiecie łańcuckim ${ }^{1}$. Ojciec był księdzem grekokatolickim. Kaczkowski uczęszczał do szkoły podstawowej w Leżajsku, następnie rozpoczął naukę w gimnazjum w Rzeszowie, filozofię ( 7 i 8 klasa gimnazjum we Lwowie) i ukończył studia prawnicze na Uniwersytecie Lwowskim. W okresie od 18 kwietnia 1832 r. do 2 lipca 1833 r. był asesorem przy Galicyjskim Sądzie Apelacyjnym we Lwowie. Pracował później także jako radca prawny w sądzie w Samborze i Wiśniczu koło Bochni. Kaczkowski pomagał finansowo studentom i pisarzom. Sam pisał: „wspomagać tylko tych, którzy albo już sa albo też z pewnościa będa gorliwymi Rusinami ... wszystko co nasze narodowe utrwalić może, a w szczególności ruska mowe, ruski śpiew, ruski obrzęd ... popierać powinniśmy"2. Dzięki jego wsparciu finansowemu możliwe było wydanie Antologii ruskiej, opracowanej przez Jakowa Hołowackiego i Bohdana Dydyckiego. Zawierała ona dzieła samego Dydyckiego oraz wiersze poetów rosyjskich ${ }^{3}$. Samodziel-

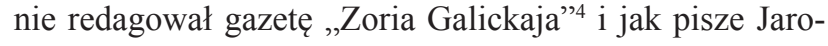
sław Moklak, należał do pokolenia Rusinów utożsamiających się z grupą tzw. „twardych Rusinów”. Jako radca

M. Grygorowicz, Czy Kaczkowski byt moskafitom? Cz. I // Nowa Zora, nr 53 z 19 lipca 1931 r., s. 6.

2 M. Grygorowicz, Czy Kaczkowski byt moskafitom? Cz. II // Nowa Zora, nr 55 z 26 lipca 1931 r., s. 6.

3 W. Osadczy, Święta Ruś. Rozwój i oddzialywanie idei prawosławia w Galicji. Lublin: Wydawnictwo Uniwersytetu Marii Curie-Skłodowskiej 2007, s. 147

4 Zoria Galicka - pierwsza gazeta ruska w Austrii, wychodząca we Lwowie.

5 J. Moklak, Michajło Kaczkowskij i czytelnie jego imienia na Łemkowszczyźnie, „Magury'87”, Warszawa 1987, s. 54.
Sądu Krajowego w Samborze, część swej pokaźnej pensji przekazywał na ruską działalność wydawniczą ${ }^{6}$. W $1848 \mathrm{r}$. Kaczkowski rozpoczął działalność publiczną i naukę języka ruskiego ${ }^{7}$. W związku z licznymi wyjazdami napisał parę artykułów dotyczących swoich podróży. Był miłośnikiem pszczelarstwa i w związku z tym wygłosił kilka wykładów na ten temat.

Na początku lat 50. XIX w. Kaczkowski zaprzyjaźnił się z Bohdanem Dydyckim. Wydana przez Dydyckiego w 1860 r. „Zoria Galicka jako Album”, poświęcona osobie nowo mianowanego metropolity Hryhoryja Jachymowycza, wywarła na Kaczkowskim ogromne wrażenie. Fakt ten zbliżył Kaczkowskiego do grupy wydawców tego wydawnictwa i zapoczątkował długoletnią przyjaźń z Dydyc$\mathrm{kim}^{8}$.

13 listopada 1860 r. złożył w kasie oszczędnościowej we Lwowie 500 guldenów jako fundusz fundatorski przeznaczony na ruską działalność wydawniczą. Zdaniem Klausa Bachmana, Kaczkowski „przeznaczyt majątek na cele ruchu prawostawnego"9. W $1861 \mathrm{r}$. narodowcy utworzyli grupę pod nazwą „Młoda Ukraina” głoszącą hasło jedności i niezależności narodu ukraińskiego, wolnego od „wpływów polszczyzny i moskalofilstwa” ${ }^{\prime \prime}$. Program zawarli w kilku efemerycznych pismach: „Weczernyci”

\footnotetext{
Tamże, s. 55.

7 Tamże, s. 55.

8 Tamże, s. 56.

K. Bachman, Tto polityczne ekspansji prawosławnej na terenie Galicji przed wybuchem I Wojny Światowej. // Polska-Ukraina 1000 lat sąsiedztwa. Południowo-Wschodni Instytut Naukowy w Przemyślu, Pod. red. S. Stępnia, Przemyśl 1990, s. 83.

10 J. Moklak, Michajto Kaczkowskij ..., s. 56.
} 
(1862), „Meta” (1863) i „Nywa” (1865). Kaczkowski nie związał się z tą grupą.

W 1860 r. powstały w Galicji dogodne warunki dla działalności wydawniczej. Dedycki przy pomocy finansowej Kaczkowskiego rozpoczął wydawać we Lwowie czasopismo „Słowo”, wydawanego przez 27 lat (1861-1887). Ponadto Kaczkowski, jako mecenas piśmiennictwa ruskiego, przez trzy lata wypłacał miesięcznie redaktorowi „Słowa”, tj. Dydyckiemu honorarium w wysokości 40 zł reńskich $^{11}$. Po raz pierwszy „,Stowo" pojawiło się 25 stycznia 1864 r. i od razu miało duże zainteresowanie. Już w pierwszym roku liczba prenumeratorów wzrosła do $1500^{12}$.

W 1864 r. Kaczkowski złożył w Narodnym Domu we Lwowie testament. Zaznaczył w nim wyraźnie, że majątek przez niego pozostawiony ma być wykorzystany na wydawanie ruskich czasopism o charakterze narodowym i na nagrody dla autorów prac w języku ruskim. Na rok przed śmiercią, w 1871 roku, Kaczkowski uznając za celowe wprowadzenie uzupełnień, wprowadził aneks do testamentu: w sprawie konkursów literackich dodał wówczas, należy nagradzać tylko takie utwory, które bliskie są duchem redakcji ,Stowa”, ,Uczitiela” $i$,,Lastowki”. Język tych artykułów powinien być taki sam jakiego używają te redakcje ${ }^{13}$.

20 kwietnia 1972 r. Kaczkowski przeszedł na emeryturę i udał się w podróż do Szwecji i Rosji, która jak się wkrótce okazało była ostatnią. Umiera 20 sierpnia 1872 w Kronsztadzie ${ }^{14}$.

$\mathrm{Z}$ początkiem lat 70. przewodnictwo w stronnictwie po Dydyckim przejął ks. Iwan Naumowicz. 19 sierpnia 1874 roku, z inicjatywy ks. Naumowicza i dyrektora gimnazjum w Bochnie Fieodora Bielousa w drugą rocznicę śmierci Kaczkowskiego, założono w Kołomyi Towarzystwo im. Michała Kaczkowskiego, towarzystwo oświatowe. Brat Fieodora Bielousa, Michał drukarz, zamieszkał w Kołomyi i otworzył drukarnię, w której rozpoczęto wydawanie gazety „Ruskaja Rada” oraz publikacji towarzystwa ${ }^{15}$. Towarzystwo nie tylko wydawało literaturę, ale organizowało czytelnie oraz kursy: ogrodnictwa, handlu, produkcji mlecznej i hodowli zwierząt itp. ${ }^{16}$ Doroczne zjazdy członków Towarzystwa były wielkim wydarzeniem ${ }^{17}$.

Z 1874 r. cała Łemkowszczyzna zaczyna się pokrywać siecią czytelni Towarzystwa im. Michała Kaczkowskiego.

\footnotetext{
11 Tamże, s. 56.

12 F. I. Swistun, Prikarpatskaja Rus pod władzienijem Austrii, Peter

S. Hardy, Hardy Lane, Trumbull, Connecticut 06611 1970, s. 230.

13 J. Moklak, Michajło Kaczkowskij ..., s. 57.

14 W. Osadczy, Święta Ruś. Rozwój i oddziaływanie idei prawosławia w Galicji, Lublin: Wydawnictwo Uniwersytetu Marii Curie-Skłodowskiej 2007, s. 528.

15 F. I. Swistun, Prikarpatskaja Rus ..., s. 417-418.

16 N. M. Paszajew, Istoria Galicziny na stranicach russkoj pressy wtoroj połowiny $X I X$ w. // Istoria, istorografiia, bibliotecznoje dieło: Matieriały konferencii specialistow Gosudarstwiennoj publicznoj istoriczeskoj bibliotieki. Moskwa 23-24 marta 1993 g., Moskwa 1994, s. 105.

17 P. R. Megoczi. Kulturnyje institucji kak instrument nacjonalnogo razwitiia w XIX w. w Wostocznoj Galicii // Sławianskije i bałkanskie kultury XVIII-XIX ww., Moskwa 1990, s. 137-137.
}

W 1876 r. Towarzystwo im. M. Kaczkowskiego zostało przeniesione do Lwowa ${ }^{18}$.

Moklak twierdzi, że „inspiracja dla Naumowycza byla zorganizowana proludowa dziatalność narodowców. W 1868 r. powstało bowiem we Lwowie ukraińskie Towarzystwo „, Proświta”, zakładajace w swym statucie ,, oświatę ludu" ... Wkrótce Naumowicz zrozumiat, że wspieranie narodowo-ukraińskiej „Proświety” nie leży w interesie jego stronnictwa. Następnie w 1873 r. narodowcy utworzyli we Lwowie Towarzystwo im. Tarasa Szewczenki ukraińskie towarzystwo naukowe" 19.

W tym okresie powołano również, organ prasowy o zasięgu ogólnogalicyjskim. Lokalnie dla Łemkowszczyzny założono w Nowym Sączu pismo „Łemko”, drukowane następnie w Gorlicach ${ }^{20}$. Skrupulatnie przystąpiono do planowej organizacji sieci czytelni im. Kaczkowskiego będących, terenowymi oddziałami Towarzystwa. Najwięcej ich istniało w powiecie gorlickim ${ }^{21}$. Jedną z pierwszych była założona czytelnia w Pielgrzymce, powstała dzięki ks. Tytowi Myszkowskiemu i w Lipowcu, założoną przez ks. Mykołę Wołoszynowicza. Przed I wojną światową istniała także dobrze prosperująca, oddziaływująca na okolicę, czytelnia w Świątkowej Wielkiej. W 1913 r. założono czytelnię w Króliku Wołoskim. Istniały także i inne oddziały terenowe Towarzystwa na Lemkowszczyźnie. Istniały także inne, o których niewiele wiadomo wobec braku dostępnych źródeł. Ich działalność została przerwana przez wybuch I wojny światowej ${ }^{22}$.

W maju 1914 r. został przygotowany przez adwokatów Konstantego Lewickiego, Fiedakowa memoriał z prośbą oddania „Ukraińcom” ruskie narodowe towarzystwa: Narodowy Dom, Stauropigialny Instytut i Towarzystwo im. M. Kaczkowskiego. Memoriał podpisało 180 osób i został złożony w urzędzie we Lwowie. W memoriale zwraca się uwagę na szkodliwą dla państwa Austrii działalność w/w towarzystw, dotujących licznych uczniów wychowywanych $w$ duchu ruskim ${ }^{23}$.

Nawet w czasie I wojny światowej przez Konstantego Lewickiego 24 listopada 1915 r. był powtórnie złożony w urzędzie we Lwowie jako donos memoriał Nr 35470/pr. Memoriał nazywał się: ,,Memorandum ukraińskiej narodowej Rady, dotyczącej reform ukraińskich urzędów, przejętych przez rusofilów we Lwowie" ${ }^{24}$.

Już w pierwsze dni wojny zaczęły się masowe egzekucje, pretekstem dla których służyły donosy o uczestnictwie w legalnych ruskich organizacjach. W gazecie „Diło” z 4 sierpnia 1914 r. Nr 172 czytamy: „Wśród „moskwofitów” we Lwowie $i$ na prowincji sa przeprowadzane rewizje

\footnotetext{
18 J. Moklak, Michajło Kaczkowskij ..., s. 58.

19 Tamże, s. 58

20 Tamże, s. 60.

21 J. Moklak, Aspekt polityczny życia religijnego Ukraińców w Galicji. Ekspansja prawosławia rosyjskiego // Polska-Ukraina 1000 lat sąsiedztwa, T. 1, Studia z dziejów chrześcijaństwa na pograniczu etnicznym pod red. Stanisława Stępnia. Południowo-Wschodni Instytut Naukowy w Przemyślu, Przemyśl 1990, s. 83.

22 J Moklak. Michajło Kaczkowskij ..., s. 61

23 Talergofskij Almanach, Wypusk 2, Lwow 1925, s. 21.

24 Tam że, s. 21.
} 
$i$ areszty. W Szczirce aresztowano: ks. Romanowskiego z Dmitria, ks. Stebielskiego z Gorbacza i psalmistę Homina ze Szczirickij. We Lwowie aresztowano dyrektora Griniewieckiego, oficjalnego przedstawiciela rosyjskiej agencji telegraficznej. Wydawnictwo „Prikarpatska Ruś” zostało zamknięte przy użyciu policji. Przeprowadzono $w$ redakcji rewizję $i$ aresztowano kilka osób z administracji, jak również z redakcji gazety. Redaktor ,Prikarpatskoj Rusi” Łabienski, razem z Dudykiewiczem, Głuszkiewiczem i innymi musieli wyjechać do Rosji" ${ }^{25}$.

4 sierpnia 1914 r. na rozkaz władz we Lwowie, jak podaje „Diło” Nr 178 z 1914 r., z dniem 5 sierpnia Narodowy Dom, Towarzystwa im. Michała Kaczkowskiego i wszystkie inne towarzystwa „moskalofilskie” zawiesiły swoją działalność. Mieniem wymienionych towarzystw zaczęli zarządzać komisarze ${ }^{26}$. Pomieszczenia zostały opieczętowane.

W 1919 r. następuje wznowienie działalności Towarzystwa im. M. Kaczkowskiego ${ }^{27}$. Przynależność do towarzystwa w czasie wojny była surowo zabroniona a w przypadku ujawnienia członkowstwa surowo karana. Najłagodniejszym karą było wywiezienie do obozu w Talerhofie. Wznowiono publikację tytułu „Wriemiennik” - organu prasowego wymienionego towarzystwa. W 1923 r. odbyło się pierwsze po wojnie posiedzenie Galicko-ruskiej maticy, rozpoczęto ponownie drukować - książki, broszury, periodyki: „Ruski Hołos”, „Ziemia i wola”, „Nauka” Towarzystwa im. M. Kaczkowskiego ${ }^{28}$. Wydano cztery wydania „Talergofskij Almanach”, na łamach, którego opublikowano dokumenty o zagładzie i mękach tysięcy Galicjan ${ }^{29}$, jednocząc wokół siebie galicko-ruskich działaczy. Wśród nich byli: doktor słowiańskiej filologii i więzień obozu w Talerhof W. R. Wawrik, oskarżony we lwowskim procesie w 1914 r. S. J. Biendasiuk, doktor J. S. Zając, poeta, krytyk, etnograf J. A. Jaworski.

W okresie między wojennym na Łemkowszczyźnie czytelnie Towarzystwa im. M. Kaczkowskiego były najpopularniejszymi czytelniami. Liczba ich sięgała około $70^{30}$. Jedną z pierwszych w tym okresie była czytelni założona w 1926 r. w Radocynie. Nie wszędzie jednak akcja spotykała się z zainteresowaniem. W Skwirtnem np. założona bez poparcia społecznego czytelnia rychło upadła, zaś mieszkańcy - jak pisał korespondent „Hołosu Naroda” z tejże wsi, zamiast czytać to ,łem ferbla hrajut”31*. Dla ułatwienia legalizacji nowo zakładanych czytelni, redakcja krynickiego dwutygodnika „Łemko” zamieszczała na swych łamach statuty i wzory gotowych deklaracji. Procedurę wstępną ograniczano do minimum, tak że dla

\footnotetext{
25 Talergofskij Almanach, Wypusk 1, Lwow 1924, s. 82.

26 Tam że, s. 82.

27 P. R. Megoczy, Kulturnyje instytucji ..., s. 141.

28 N. M. Paszajewa, Russkije dwiżenia $w$ Galiczynie XIX-XX ww. // Sławianskij Almanach, Moskwa 1999, s. 128.

29 Talergowskij almanach, Wydanie 1-4, Lwow, 1924-1932.

30 Podana cyfra nie jest dokładna, gdyż nie posiadamy wystarczających danych. Cyfra została ustawiona na podstawie Szematyzmu Apostolskiej Administratury Łemkowszczyzny z 1936 r., a pozostałe dane są zasięgnięte z WAR-Kr UWKr.

31 * ,grają tylko w werbla” - gra karciana
}

i otwarcia czytelni wystarczyły podpisy siedmiu gospodarzy danej wsi. Jednak rozwijane po 1918 r. sympatie proukraińskie okazały się na tyle żywotne, że w istotny sposób hamowały rozwój czytelni im. Kaczkowskiego. I tak np. założona w 1927 r. czytelnia w Przegoninie - Bodakach upadła z braku zainteresowania, nie pomogło nawet uroczyste otwarcie zorganizowane w rok później. Ostatecznie reaktywowano tę czytelnię dopiero w 1935 roku. Były też jednak czytelnie, które wykazywały stabilność, np. w Kunkowej, Piorunce, Pielgrzymce, powstałe w 1928 r. Rok 1928 zamykał jednak ten etap ich rozwoju ${ }^{32}$.

Do kolejnej fali rozwoju czytelni im. Kaczkowskiego doszło z początkiem 1934 roku, w związku z powołaniem do życia Administracji Apostolskiej Łemkowszczyzny (AAŁ). W 1933 r. w okresie przygotowań do utworzenia AAŁ powstała czytelnia im. Kaczkowskiego w Polanach, a w roku następnym założono czytelnie w Maciejowej, Zyndranowej, Trzciance, Kopkach i Bielicznej. W 1935 r. reaktywowano czytelnię w Króliku Wołoskim oraz założono nowe we Florynce, Izbach, Roztoce Wielkiej i w innych miejscowościach. Rok1936 przyniósł kolejne uroczyste otwarcia, m.in. w Słotwinach k. Krynicy ${ }^{33}$. Z powyższych danych wynika, że szerszy rozwój czytelni im. Kaczkowskiego na Łemkowszczyźnie miało miejsce dopiero w latach 30. XX wieku.

Ruski ruch i czytelnie Towarzystwa im. M. Kaczkowskiego, będące podstawą Towarzystwa, były lojalne w odniesieniu do polskiego państwa. Na posiedzeniu Towarzystwa im. M. Kaczkowskiego 2 kwietnia 1933 r. w czytelni, w Żdyni członkowie wystąpili przeciw działaniom niemieckiej dyplomacji w związku z zawładnięciem ziem w południowo-zachodniej Polsce ${ }^{34}$.

Dochód ze spotkań naukowo - kulturalnych był przeznaczony na zakup książek dla czytelni Towarzystwa ${ }^{35}$. Członkowie towarzystwa w Królowej Ruskiej zdecydowali się na zakup książek o tematyce rolniczej, jak również zaprenumerować gazety „Ziemia i Wola” i „Ruski Hołos"36.

Ukraińcy dążyli do przejęcia czytelni Towarzystwa im. M. Kaczkowskiego. Jeśli starania kończyły się fiaskiem wówczas manifestowali swoją dezaprobatę ${ }^{37}$. Owe nacjonalistyczne zapędy miały na celu zamianę czytelni Towarzystwa im. M. Kaczkowskiego na ukraińskie czytelnie pod nazwą Piereswiet. W Żdyni unicki ksiądz wspólnie z kierownictwem szkoły podstawowej opowiedział się za zamknięciem czytelni Towarzystwa im. M. Kaczkowskiego, by na jego miejscu otworzyć Piereswiet ${ }^{38}$.

W większości wsi istniała tylko jedna czytelnia: albo Towarzystwa im. M. Kaczkowskiego, albo Piereswiet. Mimo to, były przypadki, kiedy w jednej wsi istniały dwie

\footnotetext{
32 J. Moklak, Mychajło Kaczkowski ..., s. 62.

33 Tam że, s. 62.

34 Sprawozdanie sytuacyjne miesięczne z życia społeczno-politycznego

i mniejszości narodowych, WAP-Kr UWKr. sygn. 279, s. 161.

35 Tamże, sygn. 272, s. 48; 127. sygn. 275 , s. 38 .

36 Tamże, sygn. 277, s. 265.

37 Sprawozdanie sytuacyjne ... WAP-Kr UWKr. sygn. 275, s. 12.

38 Tamże, sygn. 277, s. 29.
} 
czytelnie obu tendencji. Tak było w Gładyszowie, Wysowej i Grabie. W Polanach 19 grudnia 1931 r. na wspólnym zebraniu obu ruchów podejmowano kwestię zjednoczenia obu czytelni. Plan nie doczekał się realizacji z uwagi na nieobecność dwóch członków Piereswiet, którzy nie przybyli na umówione spotkanie ${ }^{39}$.

Studiując działalność czytelni Towarzystwa im. M. Kaczkowskiego, należy podkreślić ich istotny związek z prawosławiem. Ich członkowie występowali przeciw Kościołowi greckokatolickiemu, jak i jej księżom. Pod adresem kościoła unickiego wysuwano oskarżenia o latynizację i polonizację obrządków, a tym samym ludność Łemkowszczyzny. Czytelnie Kaczkowskiego sprzyjały rozpowszechnieniu na Łemkowszczyźnie prawosławia. W 24 wsiach, gdzie działały tylko czytelnie Towarzystwa im. M. Kaczkowskiego, częściowo lub całkowicie mieszkańcy powrócili na łono Kościoła prawosławnego. W trzech wsiach (Grab, Polany, Florynka) działały tylko dwie czytelnie $w / w$ towarzystw. W kierowaniu czytelni

\footnotetext{
39 Tamże, sygn. 275, s. 294.
}

Towarzystwa im. M. Kaczkowskiego brali udział księża prawosławni. Ks. Pawłyszyn był prezesem czytelni w Uściu Ruskim i Czarnej ${ }^{40}$.

Były również i takie sytuacje, kiedy czytelnie Towarzystwa im. M. Kaczkowskiego jawiły się tylko przedstawicielstwem „na papierze”, ponieważ nie prowadziły żadnej działalności. O tym świadczy sprawozdanie komitetu wojewódzkiego, zajmującego się sprawami Łemkowszczyzny $^{41}$. Lecz to nie miało żadnego pośredniego wpływu na działalność, którą prowadziło Towarzystwo im. M. Kaczkowskiego na Łemkowszczyźnie.

Czytelnie Towarzystwa im. M. Kaczkowskiego odegrały istotną rolę w formowaniu łemkowskiej świadomości i zachowaniu wielu charakterystycznych Łemkom kulturalno-religijnych cech. II wojna światowa, jak i wydarzenia po niej, doprowadziły do ich ostatecznego zamknięcia.

\footnotetext{
40 Sprawozdanie sytuacyjne ... WAP-Kr Ukr., sygn. 279, s. 22, 82.

${ }_{41}$ Materiały dotyczące Łemkowszczyzny. Szkolnictwo, sprawy kulturalne, gospodarcze i inne, AAN MSW, sygn. 1058, s. 57.
}

\section{Bibliografia}

\section{Źródła archiwalne}

Wojewódzkie Archiwum Państwowe w Krakowie

Urząd Wojewódzki w Krakowie

Archiwum Akt Nowych Ministerstwo Spraw Wewnętrznych

\section{Opracowania i artykuły}

K. Bachman, Tło polityczne ekspansji prawosławnej na terenie Galicji przed wybuchem I Wojny Światowej. // PolskaUkraina 1000 lat sąsiedztwa. Południowo-Wschodni Instytut Naukowy w Przemyślu, Pod. red. S. Stępnia, Przemyśl 1990.

M. Grygorowicz, Czy Kaczkowski byt moskafiłom? Cz. I // Nowa Zora, nr 53 z 19 lipca $1931 \mathrm{r}$.

M. Grygorowicz, Czy Kaczkowski byt moskafitom? Cz. II // Nowa Zora, nr 55 z 26 lipca 1931 r.

P. R. Megoczi. Kulturnyje institucji kak instrument nacjonalnogo razwitiia w XIX w. w Wostocznoj Galicii // Sławianskije i bałkanskie kultury XVIII-XIX ww., Moskwa 1990.

J. Moklak, Michajto Kaczkowskij i czytelnie jego imienia na Łemkowszczyźnie, „Magury'87”, Warszawa 1987.

J. Moklak, Aspekt polityczny życia religijnego Ukraińców w Ga- licji. Ekspansja prawostawia rosyjskiego // Polska-Ukraina 1000 lat sąsiedztwa, T. 1, Studia z dziejów chrześcijaństwa na pograniczu etnicznym pod red. Stanisława Stępnia. Południowo-Wschodni Instytut Naukowy w Przemyślu, Przemyśl 1990.

W. Osadczy, Święta Ruś. Rozwój i oddziatywanie idei prawosławia w Galicji. Lublin: Wydawnictwo Uniwersytetu Marii CurieSkłodowskiej 2007.

N. M. Paszajew, Istoria Galicziny na stranicach russkoj pressy wtoroj połowiny XIX w. // Istoria, istorografiia, bibliotecznoje dieło: Matieriały konferencii specialistow Gosudarstwiennoj publicznoj istoriczeskoj bibliotieki. Moskwa 23-24 marta 1993 g., Moskwa 1994.

N. M. Paszajewa, Russkije dwiżenia w Galiczynie XIX-XX ww. // Sławianskij Almanach, Moskwa 1999.

F. I. Swistun, Prikarpatskaja Rus pod władzienijem Austrii, Peter S. Hardy, Hardy Lane, Trumbull, Connecticut 066111970.

Szematyzm Apostolskiej Administratury Łemkowszczyzny z 1936 r.

Talergofskij Almanach, Wypusk 1, Lwow 1924.

Talergofskij Almanach, Wypusk 2, Lwow 1925. 
ISSN 1508-7719

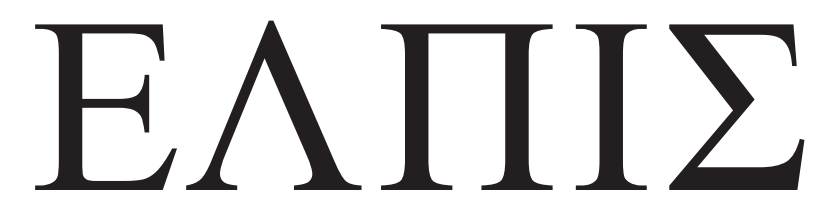

CZASOPISMO TEOLOGICZNE KATEDRY TEOLOGII PRAWOSŁAWNEJ UNIWERSYTETU W BIAŁYMSTOKU

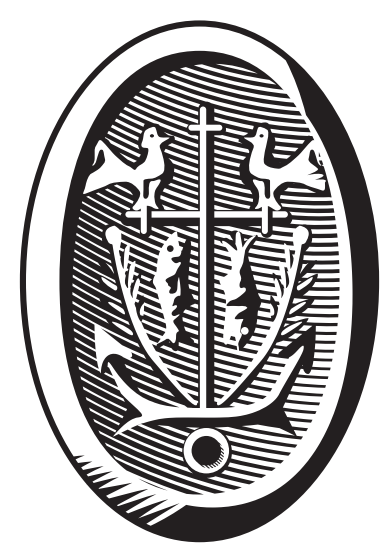

ADRES REDAKCJI

15-097 Białystok, ul. M. Skłodowskiej-Curie 14 tel. 85 745-77-80, e-mail: redakcja@elpis.edu.pl www.elpis.uwb.edu.pl 